\title{
Teacher Education- Globalization Framework
}

\author{
Mrs. Sapna Mishra \\ (lecturer,pursuing Ph.d) Maya devi institute of advance studies Residence: B-4/2 vikram university campus \\ kothi road ujjain 456010
}

\begin{abstract}
No doubt, Higher Education has attained a key position in the knowledge society under globalised economy. However, the challenges faced are immense and far-reaching. Its impact on the clientele viz., Individuals, Institutions, Systems and Societies is not only not clear but also not comprehendible at this moment unless it is viewed in the context of various other factors that are simultaneously operating on the higher education system. Some agree that the rapid cross national flows of people, goods, capital and information may dissolve the nation State, push institutions (university is the one) into a common mould where as others disagree. It is assumed that globalization promises dramatic and rewarding change to the higher education systems, of societies, which are relatively stable in their political, social and institutional makeup, while for the others, it may threaten the very stability needed to build well performing higher education system. It is also true, that so far globalization has given the advanced economies a huge advantage as they had made enough preparation prior to its launching while others are caught in the trap without any preparation.
\end{abstract}

\section{Globalization;}

As it is known globalization, no doubt, promises dramatic and rewarding change to the higher education systems of the developed countries. Where as for the developing and the underdeveloped countries, where the system is facing the scarcity of resource, it threatens the stability needed to build the well performing system.Developing countries often have to adjust willingly or unwillingly both to the quickening pulse of international change, and accordingly, reform on several fronts simultaneously, which may not be possible under the given resource status of higher education.

Globalization is expected to be a process through which an increasingly free flow of ideas, people, goods, services and capital would lead to the integration of economies and societies. It is characterized by an accelerated flow of trade, capital, and information, as well as mobility of individuals, across geographical borders. It reflects comprehensive level of interaction than that has occurred in the past, suggesting something beyond the word "international". It implies a diminishing importance of national borders and strengthening of identities, that stretch beyond those rooted in a limited locale in terms of particular country or region. It can also be defined as the intensification of worldwide social relations which link distant localities in such a way that local happenings are shaped by events occurring at any distant place and vice versa. It is this construction of time-space compression that has given rise to popular notion of "One-World" "Global Village", etc.

The basic pillar of globalization is economy, a terrain which has seen the world turn into a global hub. The organizations like WTO and agreements like GATS (General Agreement on Trade \& Services) have broken the barriers between nations and economy has become the buzzword of the world. In post globalization era it has become increasingly important to be knowledgeable about economy, so the traditional teacher education courses will have to have economy and finance as a compulsory part of curriculum. This knowledge should be introduced in every stream of teacher education so that the future teachers can pass the baton of their enhanced knowledge to their pupils.

E- commerce courses has been given priority by the government but still a lot needs to be done in this arena.

Last twenty years have seen a revolutionary change in the use of information and technology and no wonder that software giants like US \& India and hardware giants like China \& Japan are global leaders in the present scenario. Information and technology have been given special preference in the general curriculum during the recent years but teacher education centres have not been equipped to cope up with the new realities so a change is needed to make teacher education enters more equipped in IT and further IT should be made an essential part of the curriculum. On line submission of forms, using teaching aids like LCD and making preparation for online examinations in future should be a part of long term policy.

The globalization has seen a reducing interference of government in the social sector. The growing cost of education has seen a rapid growth in self finance education centers and courses. The paucity of time has led to a phenomenal rise in distance education programs. The self finance courses which has been a outcome of globalization has made a adverse impact on the financially deprived sections of society so it will be advisable to have more government support for teacher education which is a popular stream in every strata of the Indian society. More government aided and supported teacher education institutions are the need of the day. Further the 
distance education programs especially in teacher education curriculum are not a plausible idea because it includes a lot of pragmatic and practical knowledge which can't be imparted from distance.

Globalization is a reality now and Developing countries like India will have to cope with its nuances the transformations extends to the teacher education sector and it is high time that we adopt ourselves for a glittering and glorious future.

The Administrative set up in democracies like India has also seen a seaward change in the recent years. Increasing use of Information and technology with E- governance making its root has been a befitting trend in Indian Administrative set up. Teacher education should be well equipped with the practical knowledge of Egovernance and other administrative nitty gritties. The teacher curriculum courses should look futuristic and implement E-governance as a basic content of the curriculum this knowledge will have a grass root value and will be traversed to every nook and corner of India making every Indian more equipped with his rights and making India a glorious democracy carving a niche for itself in this world.

There has been a very positive impact of globalization as there has been a gradual flow of knowledge bridging the barriers of nationalities. The overall education scenario and especially teacher education has seen a general enrichment as there is availability of valuable and prized thoughts of world famous writers on various aspects on internet. This has received a further impetus as the publishers are now having an eye on a highly potential market like India. Our education system has seen a great improvement by this phenomenon.

Globalization has created distances between the resourceful \& rich countries and deprived nations of the world. There has been an exodus of efficient personnel's in the field of education to greener pastures in the developed countries. The phenomenon is also visible in the teacher education sector depriving India of its valuable assets so time has some that salary structure in the teacher education scenario be improved so this exodus or brain drain that has resulted due to globalization could be curbed at this stage and we are able to get diligent and intelligent eservices in this sector.

Last few decades has seen a tremendous growth in teacher education. There have been a great increase in the number of teacher training institutes but sadly quantity has been given emphasis over quality. It is an urgent need to come up with quality based education system as in countries like Japan. Yes India is in dire need of great number of teachers bat they have to be made pass through stringent quality based programs so that they grow up with all round development and produce batter results in future.

Globalization though has contributed for rise in living standards, improvement in health and education and Technology advancement, especially in the area of communication and computers during this period, yet in the recent past, there have been apprehensions expressed in terms of its impact, especially on the people who still live below the poverty line and the question that is being raised repeatedly is "will they also equally share the benefits?" if not equal, then "what will they get"? More than these "What is that which is typical Indian and is known to be precious and pride of the country that both the groups i.e. "haves" and "have nots" have to loose?

\section{In other words, the concerns expressed are with regard to:}

(i) Benefits of globalization to the different sections of the society -it is believed to be "far uneven".

(ii) Its role in creating greater social stratification and inequality -widening the gaps between the "haves" and "have not's".

(iii) Its role in destabilizing and distorting the indigenous culture, tradition and values.

(iv) Its role in alienating the youth from its own place by uprooting and at the same time not sure of providing a landing space.

(v) More than these, its role in facilitating the rich countries to grow richer by drawing the resources from the poor.

\section{References:}

[1]. John Smyth, "Globalization and Higher Education: What's Happening to Academic Work?" in Ninth World Congress on Comparative Education: Tradition, Modernity, and Post modernity (Sydney) Proceedings, 1996) and John Smyth, ed., Academic Work: The Changing Labour Process in Higher Education (Buckingham: Society for Research into Higher Education and Open University Press, 1995.

[2]. Government of India (1997) Approach paper to the ninth Five year plan: 1997-2002, Planning Commission, New Delhi.

[3]. Rani, Geetha, P. (2003) Financing Education in India in the Economic Reform Period: Focus on Intra Sectoral Allocation of Resources to education, in Globalization and Challenges of Education, NIEPA, 2003.

[4]. The Globalization of India economic: a need for internationalization of Higher Technical Education (Patil \& Pudlowski)

[5]. Philip G. Altbach, Higher Education and the WTO: Globalization Run Amok, Chronicle of Higher Education.

[6]. Open Doors 2004, Report on International Educational Exchange, Institute of International Education

[7]. World Bank, World Development Report 2000/2001: Attacking Poverty.

[8]. (New York: Oxford University Press, 2001), p. 276 and p. 280. Telephone estimate from Financial Times. 